\section{FYSIEKE AFSPRAAK}

Kankerpatiënten waarderen in coronatijd de mogelijkheid tot videobellen en telefonische afspraken, maar acht op de tien mensen wil het liefst een fysieke afspraak met hun arts of verpleegkundige. Dit blijkt uit een peiling van de Nederlandse Federatie van Kankerpatiëntenorganisaties (NFK).

\section{RICHTLIJN DIABETES}

De nieuwe voedingsrichtlijn van de Nederlandse Diabetes Federatie bevat handvatten om patiënten en zorgverleners te ondersteunen bij het nemen van beslissingen over passende voedingszorg. Je vindt de voedingsrichtlijn op de website zorgstandaarddiabetes.nl en in de NDF Toolkit Persoonsgerichte diabeteszorg en -preventie.

\section{MENTALE GEZONDHEID}

Stichting IZZ luidt de noodklok: de mentale gezondheid van jonge zorgmedewerkers is zorgelijk en leidt tot uitval en uitstroom die de gezondheid van de zorg en daarmee van Nederland bedreigt. Het psychische zorggebruik van jonge zorgmedewerkers is sinds 2015 met 40 procent gestegen en hun verzuim met 10 procent.

\section{UITGESTELDE ZORG}

Huisartsen hebben in 2020 door COVID-19 12 procent minder verwijzingen naar vervolgzorg gedaan dan verwacht. Landelijke cijfers afkomstig van zorgplatform ZorgDomein laten zien dat sinds half maart tot 15 december 1.746 .745 verwijzingen en aanvragen naar vervolgzorg niet hebben plaatsgevonden.

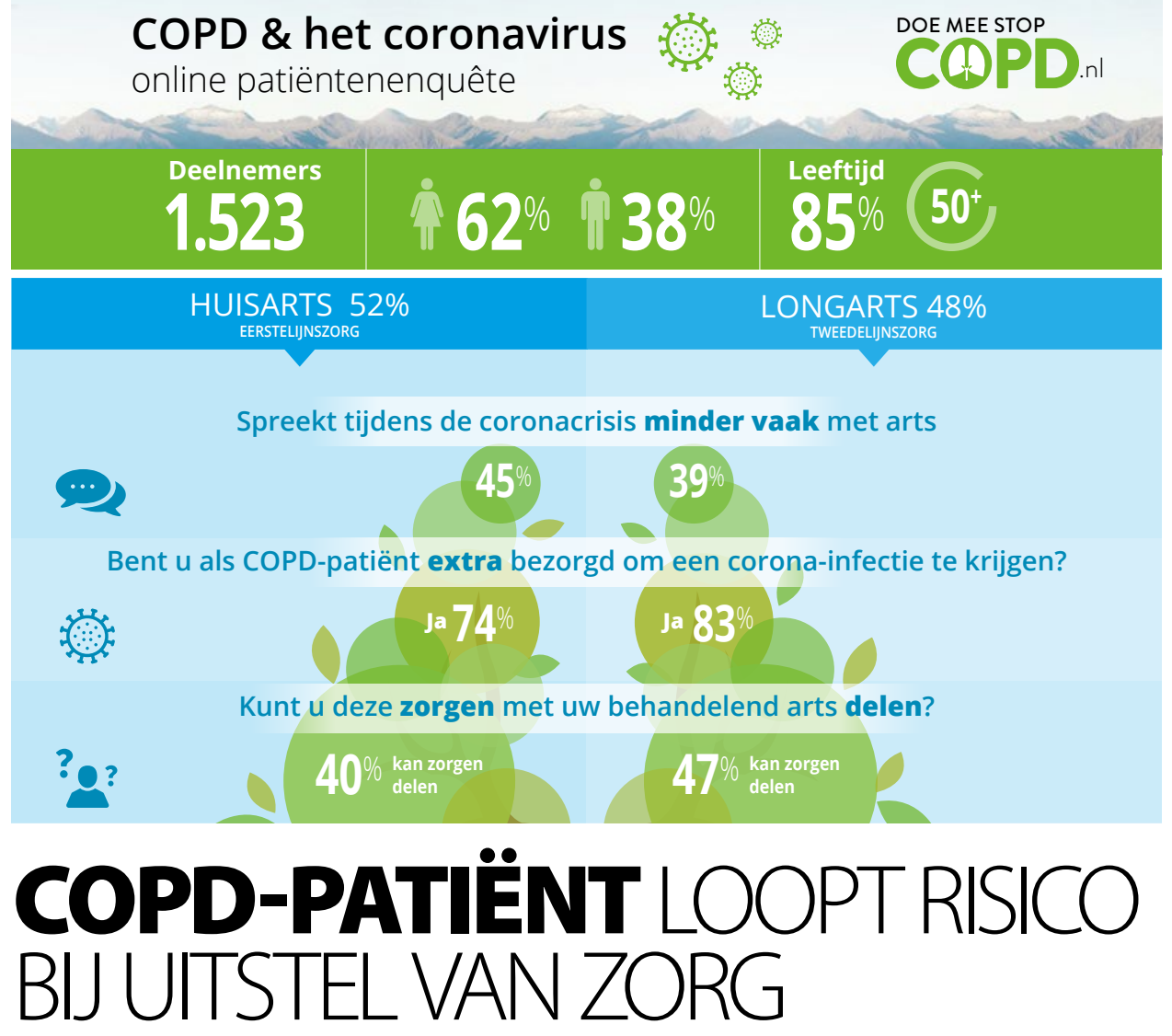

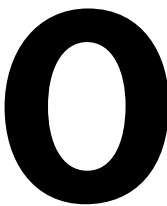

p de website doemeestopcopd.nl zijn patiënten met COPD opgeroepen om hun ervaringen en zorgen rondom het coronavirus te delen.

Meer dan 1.500 patiënten die het coronavirus niet hebben gehad, hebben deze vragenlijst ingevuld. Uit de resultaten blijkt dat het merendeel van de afspraken in de reguliere COPD-zorg vaker werd afgezegd of verplaatst. Opvallend zijn verschillen tussen de huisartsen- en de specialistische zorg. In de infographic (op www.doemeestopcopd.nl) vind je meer informatie over de uitkomsten van de vragenlijst.

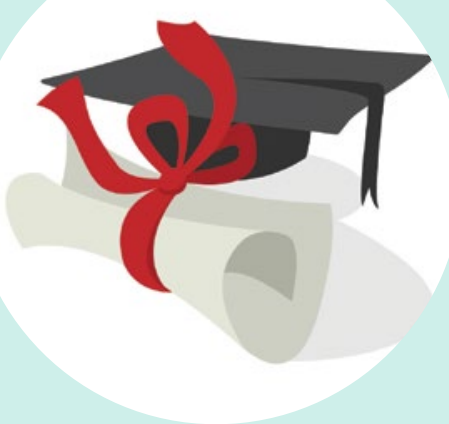

\section{Pilots nieuwe opleiding tot pvh}

Stichting Sociaal Fonds Huisartsenzorg (SSFH) is akkoord gegaan met het initiatief om te starten met de implementatie van de Praktijkverpleegkundige Huisartsenzorg (pvh). Met de start van twee pilot-opleidingen in 2021 wil SSFH ervoor zorgen dat er zowel modulair als regulier kan worden opgeleid. Daarnaast heeft SSFH aangegeven dat door- 


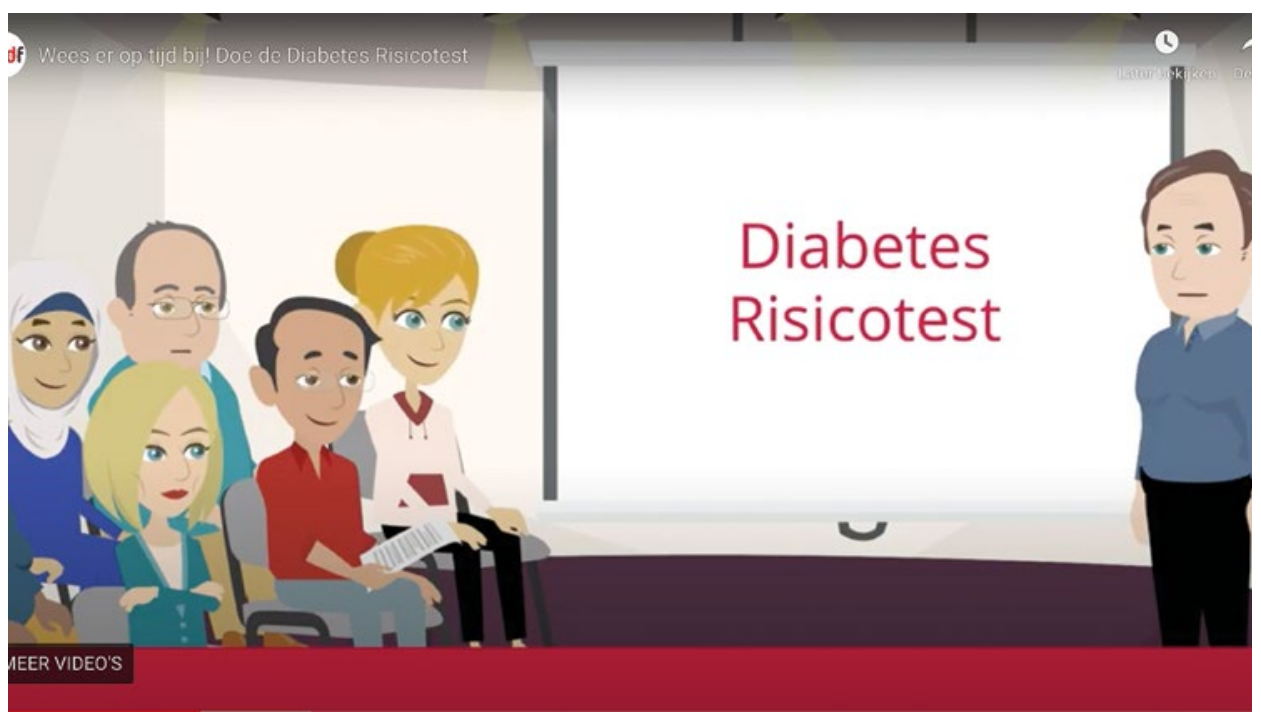

\section{VROEGOPSPORING}

45 jaar of

ouder?

Doe dan de test!

\section{Diabetes Risicotest heeft nu een eigen website}

De Diabetes Risicotest is een instrument voor vroegopsporing van diabetes type 2. De online test (diabetesrisicotest.online) is wetenschappelijk onderbouwd en gevalideerd. De nieuwe site opent met een filmpje met uitleg over de test. De centrale boodschap luidt: bent u 45 jaar of ouder, doe dan elk jaar de Diabetes Risicotest.

Omdat mensen met een Marokkaanse, Turkse, Afro-Surinaamse of Hindoestaanse achtergrond een grotere kans hebben op het krijgen van diabetes type 2, is de boodschap voor deze groepen gespecificeerd. Bron: NDF stroom en zij-instroom mogelijk moeten zijn voor potentiele pvh'ers. Dit wil zij bewerkstelligen door het invoeren van een assessment dat gericht is op het kunnen uitoefenen van de pvh-rol.

De pilot-opleidingen moeten leiden tot het toekennen van een diploma Praktijk Verpleegkundige Huisartsenzorg voor de twee groepen studenten die aan deze pilots deelnemen en de studenten die daarna de pvh-opleiding gaan volgen.
SSFH werkt momenteel aan de laatste details van het plan van aanpak voor de pilots en het onafhankelijke assessment. Het doel is om in januari 2022 de eerste gediplomeerde pvh'er het werkveld te laten betreden. De komende periode zullen regelmatig updates over het verloop van het voorbereidingsproject en de pilots gepubliceerd worden op www.ssfh.nl.

Bron: www.pvkpoh.nl

\section{HARTFALEN}

\section{Landelijke campagne}

November vorig jaar is de landelijke hartfalencampagne van start gegaan. Het doel is om mensen met symptomen die bij hartfalen kunnen passen eerder in beeld te brengen bij de huisarts. Bij mensen boven de 60 jaar zijn er naar schatting meer dan 250.000 met niet-herkend hartfalen. Door de diagnose hartfalen eerder te stellen, kan de behandeling eerder worden gestart, waardoor mensen een betere kwaliteit van leven behouden. De Hartstichting zorgde vorig jaar voor voorlichting in de wachtkamers van 4.450 huisartspraktijken. Tevens zijn er 350.000 magazines verstuurd met uitleg over hartfalen. Het magazine bevat de hartenkaart, een hulpmiddel om te bepalen of het verstandig is om de huisarts te raadplegen. De effecten van de campagne worden geëvalueerd met het NHG en (kader)huisartsen.

Bron: NHG 


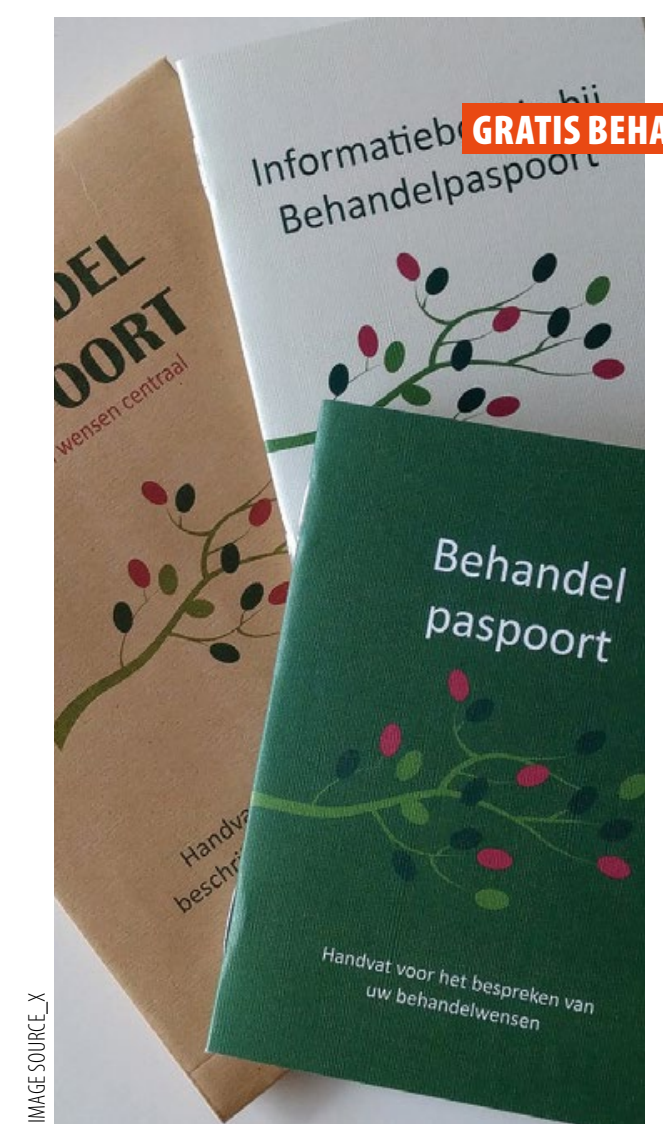

Het Behandelpaspoort is een boekje dat mensen kan helpen om hun behandelwensen te formuleren. Het is ontwikkeld door voormalig huisarts en ouderenarts Ester Bertholet, in samenspraak met een grote groep ouderen. Zij zag in haar praktijk dat patiënten behoefte hadden aan houvast bij het voeren van gesprekken over hun behandelwensen.

Het paspoort, dat inmiddels een jaar op de markt is, is niet alleen voor kwetsbare ouderen bestemd. Op elk moment in het leven kan het goed zijn aan te geven wat belangrijk is voor iemand.

Met het Behandelpaspoort heeft de patiënt een instrument tot zijn of haar beschikking waarmee wensen aangaande behandeling en zorg kunnen worden vormgegeven.

Eind vorig jaar zijn vijf nieuwe versies van het Behandelpaspoort uitgebracht: een versie voor slechtzienden, een Makkelijk lezen-versie, een Turkse versie, een Marokkaans-Arabische versie en een Engelse versie.

Meer informatie vind je op www.behandelpaspoort.nl. Bron: LHV

\section{GEZONDE LEEFSTIJL VERSTERKT HET IMMUUNSYSTEEM}

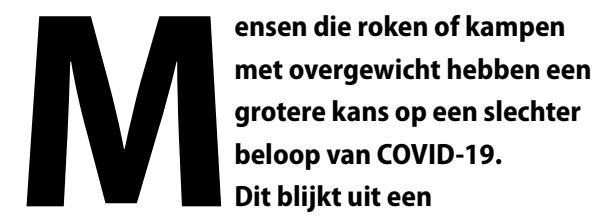

wetenschappelijke publicatie van het Leids Universitair Medisch Centrum (LUMC), Erasmus MC en het Amsterdam UMC.

Het ernstiger beloop van de ziekte bij mensen met overgewicht komt met name door een chronisch minder goed functionerend immuunsysteem. Hierdoor krijgt het SARS-CoV-2 virus zeer waarschijnlijk extra kans om zich te vermenig- vuldigen. Dit kan een forse mate van ontsteking en vaak ook trombose veroorzaken. Een verstoord immuunsysteem is op korte termijn te beïnvloeden. Bij mensen met obesitas die door een leefstijlinterventie slechts een paar procent in gewicht (vetmassa) kwijtraken, gaat het immuunsysteem op meerdere fronten al beter werken. Een gezonde leefstijl in het algemeen (gezonde voeding, voldoende beweging, slaap en ontspanning, stoppen met roken en alcohol matigen) zal het immuunsysteem versterken.

Aanbevelingen voor een betere leefstijl kun je vinden op de website Leefstijlencorona.nl.

Bron: LUMC 

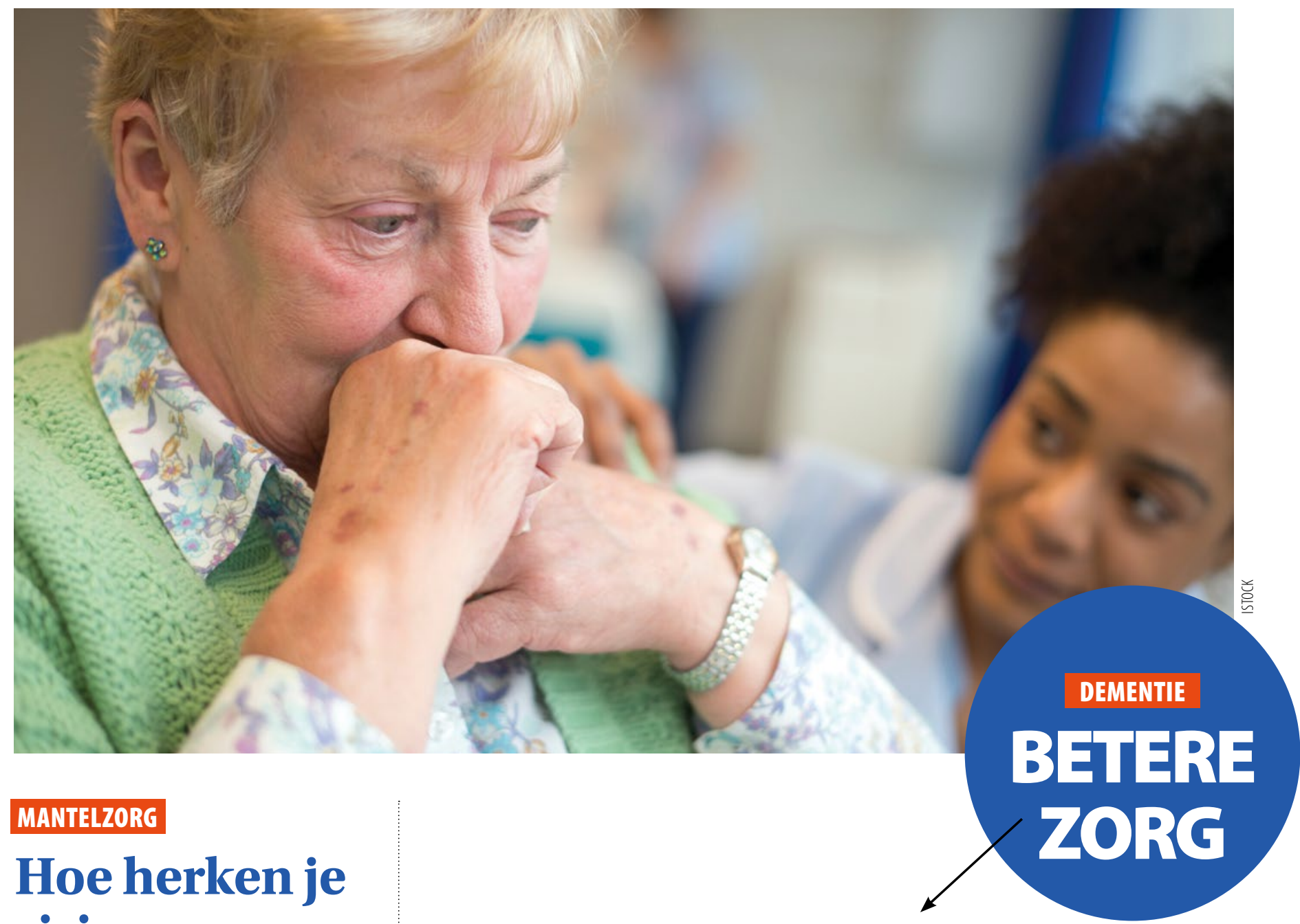

MANTELZORG

\section{Hoe herken je risicogroep en overbelasting?}

In de vernieuwde toolkit'Mantelzorg en (over) belasting'vind je informatie over wat onder mantelzorg valt, wie tot de risicogroepen behoort, hoe je overbelasting herkent en waarnaar je kunt doorverwijzen. Meer aandacht voor de mantelzorger leidt (indirect) tot betere kwaliteit van de zorgverlening. De toolkit is gemaakt in samenwerking met Vilans, MantelzorgNL en Movisie.

\section{Nieuw instrument meet dementie sneller en nauwkeuriger}

Om mensen met dementie goed te kunnen behandelen en begeleiden, is het belangrijk inzicht te krijgen in het verloop van hun ziekte. Bestaande meetinstrumenten kunnen geen verbetering of verslechtering in beeld brengen, waardoor het moeilijk is om de effectiviteit van een nieuwe behandeling vast te stellen. Onderzoekers van het Alzheimercentrum Amsterdam ontwikkelden de Cognitive-Functional Composite (CFC). Patiënten leggen een korte test af die veranderingen vastlegt op cognitief gebied, zoals geheugen en planning. Daarnaast vult de mantelzorger een vragenlijst in die problemen van de persoon in het dagelijks leven in kaart brengt. Door de combinatie van het cognitieve en het alledaagse functioneren ontstaat een goed beeld van het verloop van de ziekte.

Gedurende een jaar werd de test vier keer afgenomen bij ruim honderdvijftig mensen met geheugenklachten, milde cognitieve stoornissen of de ziekte van Alzheimer. De onderzoekers vergeleken de resultaten met de uitkomsten van de bestaande testen en met biologische maten van achteruitgang, zoals hersenkrimp. Het nieuwe meetinstrument blijkt nauwkeuriger en sneller te zijn dan de bestaande tests. Ook brengt het nieuwe instrument het verloop van de ziekte beter in beeld. Bovendien ervaren mensen met dementie het instrument als minder belastend dan de bestaande tests. De CFC draagt bij aan betere zorg voor mensen met dementie, betere communicatie tussen zorgprofessionals en een effectievere evaluatie van nieuwe behandelingen.

\section{Bron: ZonMw}

